\title{
Innehåll i tidigare nummer av Arkiv
}

\author{
NR I (2OI3)
}

Bo Rothstein, "Antikorruption - big bang-ansatsen"

Ellinor Platzer, ”Vem ska sköta hemarbetet? Hushållstjänsternas betydelse för upprätthållandet av mellanskiktens livsmönster och könsarbetsdelning"

Jessica Hansen, ”Från idé till organisatoriskt nätverk. Föreningslivets förändring och förtätning i Hovmantorp"

Risto Alapuro, "En marxistisk tolkning av Estland efter kommunismen"

Per Dannefjord \& Magnus Eriksson, "Punk, klass och karriär"

\section{NR 2 (2013) Det vita fältet II. Samtida forskning om högerextremism}

Carl Dahlström \& Peter Esaiasson, ”Invandringsfrågan och möjligheter för invandringsfientliga partier att lyckas i Sverige"

Ov Cristian Norocel, "Konstruktionen av högerradikala populistiska maskuliniteter i Sverige. En feministisk analys"

Anders Hellström, "Varför vi älskar att hata Sverigedemokraterna"

Ralf Wiederer, "En kartläggning av det högerextrema nätverket på internet strukturella mönster 2006-20II"

Emma Arneback, "Bemötanden av främlingsfientlighet i gymnasieskolan"

Wolfgang Benz, "Antisemitismforskning som akademiskt ämne och allmän uppgift"

DET VITA FÄLTET SPECIAL: RÄTTEGÅNGEN MOT BREIVIK

Mattias Gardell, ”Anders Behring Breiviks politiska hemvist och motivbild. Sakkunnigrapport inför rättegången i Oslo, 4 juni 2012”

$$
\text { NR } 3 \text { (2OI4) }
$$

Lars Harrysson \& Erika Werner, ”Bland vita, svarta och grå 'svanar' i det reformerade svenska pensionssystemet"

Stefan Svallfors, "Politik som organiserad kamp - nya spelare och nya spelregler i Sverige"

Göran Therborn, "Klass i det tjugoförsta århundradet"

Göran Therborn, "Nya massor? Motståndets sociala grundvalar" 


$$
\text { NR } 4 \text { (2OI5) }
$$

Urban Lundberg, "Åldrande och olja. Norsk pensionspolitik i internationell belysning"

Majsa Allelin, "Att orientera sig i skolan, staden och svenskheten. Det fria skolvalet enligt elever i förorten"

Sylwia Koziel, "'De tyckte att de var finare'. En adressatstudie om föräldrastöd för småbarnsföräldrar i Tyskland"

Nazem Tahvilzadeh, ”Till frågan om representation och byråkratin.

Minoritetsadministratörers företrädarpraktiker i offentliga organisationer"

Bo Rothstein \& Eric M. Uslaner, ”Alla för alla. Jämlikhet, korruption och socialt förtroende"

NR 5 (20I6) Det vita fältet III.

\section{Samtida forskning om högerextremism}

Adrienne Sörbom \& Magnus Wennerhag, ”Begreppet extremism - en kritisk introduktion"

Markus Lundström \& Tomas Lundström, "Hundra år av radikal nationalism”

Cas Mudde, "Tre decennier av populistiska radikalhögerpartier i Västeuropa"

Benjamin R. Teitelbaum, "Ignorerade band. Politik och ofullständiga ontologier i forskning om Sverigedemokraterna"

Daniel Köhler, ”Högerextrem terrorism och ultramilitans som gruppfenomen?

Gruppens inverkan i högerextrema radikaliseringsprocesser"

Tine Hutzel \& Daniel Köhler, "Högerextrem vardagsterrorism i Tyskland. Exemplet Ballstädt"

\section{NR 6 (20I6)}

Karin Edberg, ”Från motsatsförhållande till symbios? Miljöpolitik och välfärd i ekonomiska upp- och nedgångar"

Karin Alexanderson, ”Evidensbaserad praktik för lärande och utveckling i välfärdsorganisationer"

FESTSKRIFTSAVDELNING: GÖRAN THERBORN 75 ÅR

Anita Göransson \& Karin Widerberg, "Göran mellan kön och makt"

Mats Svegfors, "På spaning efter den tid som kommer"

Olle Svenning, "Min förste magister i kritiskt tänkande"

Gunnar Olofsson, ”Tidskriften Zenits bokutgivning 1968-1982" 
NR 7 (2017) Från perestrojka till Bolotnaja.

Utvecklingen av ett ryskt civilsambälle

Zhanna Kravchenko, "Inledning"

Aleksandr V. Šubin, "Den sensovjetiska sociala mobiliseringen: neformaly-rörelsen under perestrojkan"

Carine Clément, "Arbetarmobiliseringen i Ryssland från slutet av 1980-talet till i dag"

Aleksej Sachnin, "Bolotnajarörelsen: politisk kultur, identitet och mobilisering"

Oleg Žuravlev, "Vad blev kvar av Bolotnajatorget? En nystart för den lokala aktivismen i Ryssland"

NR 8 (2017)

KLASSIKERAVDELNING: EKONOMIN SOM INRÄTTAD PROCESS

Gunnar Olofsson \& Anders Hylmö, "Inledning"

Karl Polanyi, Conrad M. Arensberg \& Harry W. Pearson, "Ekonomins plats i samhället" Karl Polanyi, "Ekonomin som inrättad process"

ARTIKLAR

Erik Olin Wright, "Den kapitalistiska staten och möjligheten till socialism"

Lena Gunnarsson, "Natur, kärlek och den manliga maktens gränser"

Risto Alapuro, "Demonstrationer i Finland"

RECENSIONER

Lovisa Broström, "Den osynliga motparten"

Anders Björnsson, "Inblickar i revolutionärernas Europa"

Christian Andersson, "Musik och politik - på vilket sätt är en politisk blåsorkester politisk?"

Anders Björnsson, "En solitär på barrikaden"

Ingvar Johansson, "Vänsterutilitaristens självbiograf"

\section{NR 9 (2018) Platskamp}

Magnus Dahlstedt, Lisa Kings \& Nazem Tahvilzadeh, "Platskamp: inledande reflektioner"

Magnus Dahlstedt \& James Frempong, "Stå upp för orten. Ungdomar, utanförskap och förortsdrömmar"

René León Rosales \& Aleksandra Ålund, "Aktivism som platskamp. Självpositionering och medborgarskapande inom den svenska förortsrörelsen"

Lisa Kings, "Betydelsen av brobyggare. Det etablerade civilsamhället och förortsrörelsen"

Nazem Tahvilzadeh \& Lisa Kings, "Att göra kaos. Om förortspolitiken som urban styrregim och demokratiskt spel"

Vanja Lozic, "Att lära av det lokala och experimentera. Resilienstänkande i brottsförebyggande arbete"

Magnus Dahlstedt \& Christophe Foultier, "Förändringens agenter. Om skola, prevention och fostran till trygghet" 
ARKIV | NR II

\author{
NR IO (20I9) \\ RIKSDAGSVALET 2018
}

Göran Therborn, "Solen går ner över svensk socialdemokrati”

Björn Fryklund \& Sigrid Saveljeff, "Det politiska etablissemangets strategier gentemot högerpopulistiska partier"

Christian Gerdov, "Lika för alla?"

ARTIKLAR

Tage Alalehto, "När kom kapitalismen till Tornedalen?"

Jonas Axelsson, Jan Ch. Karlsson \& Egil J. Skorstad, ”Arbetarkollektivet i dag

- ny studie och teoretisk utveckling"

KOMMENTAR

Ingvar Johansson, "Popper och marxismen"

RECENSION

Christian Berggren, "Handelshögskolan” 